\title{
The relationship between burnout, empathy levels and interest in social activities of medical school students: Two-centre study
}

\section{Tıp fakülltesi öğrrencillerinin tükenmişlik, empati düzeyleri ve sosyal etkinliklere olan ilgileri arasındaki ilişki: İki merkez çalışması}

\author{
Naim Karagöz ${ }^{1}$, Duygu Ayhan Başer² ${ }^{2}$ Hatice Küçükceran ${ }^{3}$ Ezgi Ağadayı1*
}

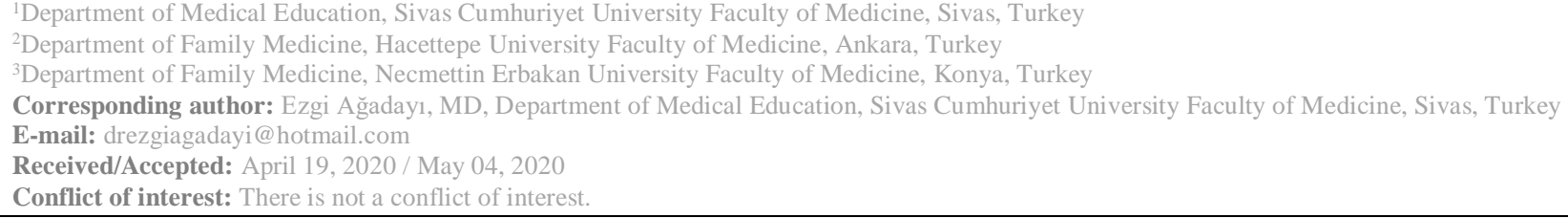

\section{SUMMARY}

Objective: The aim of this study observing the artistic/social activities of medical school students from two different faculties and evaluating the relationship of doing artistic/social activity and burnout risk and empathy levels of students.

Method: This is a descriptive study conducted at Cumhuriyet University Medical School and Necmettin Erbakan University Medical School, Turkey. The data was collected through an online survey. The survey included questions about demographic data and frequencies of participation in artistic-social activities. Determinant Scale for Opinions about the Art (DSOA), Maslach Burnout Inventory-Student Scale (MBI-SS), and Basic Empathy Scale (BES) also applied.

Results: Four hundred and thirteen students participated in the study. While $64.2 \%(n=265)$ of the students thought that "Art" and "Medicine" were related, the rate of those who wanted such an education in the Faculty of Medicine curriculum was only $40.2 \%(n=166)(p<0.001)$. The scores of the female students in DSOA were significantly higher than the male students $(\mathrm{p}<0.001)$. The burnout risk of students was $54.5 \%$. In the comparison of the scale scores according to participation frequency in artistic/social activities, there were significant differences in cynicism subscale of MBI$\mathrm{SS}(\mathrm{p}=0.013)$, affective subscale of BES $(\mathrm{p}=0.015)$ and cognitive subscale $(\mathrm{p}=0.001)$ of BES.

Conclusions: In conclusion, these results support that engaging in artistic activities reduces students' burnout levels and increases empathy levels. It could help reduce students' burnout levels by adding artistic courses or providing the conditions that can reach these activities to the faculty students who have severe educational conditions such as medical school.

Keywords: Art, burnout, empathy, medical students

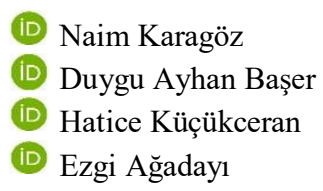

ORCID IDs of the authors: N.K. 0000-0002-6456-1128 D.A.B. $0000-0002-5153-2184$

H.K. 0000-0002-0581-9934

E.A. $0000-0001-9546-2483$ 
Amaç: Bu çalıșmanın amacı, iki farklı fakülteden tıp fakültesi öğrencilerinin sanatsal / sosyal faaliyetlerini incelemek ve öğrencilerin sanatsal / sosyal aktivite ile tükenmişlik riski ve empati düzeyleri arasındaki ilişkiyi değerlendirmektir. Yöntem: Bu tanımlayıcı tipte çalışma, Cumhuriyet Üniversitesi Tıp Fakültesi ve Necmettin Erbakan Üniversitesi Tıp Fakültesi'nde yürütüldü. Veriler çevrimiçi bir anket aracılığıyla toplandı. Ankette demografik veriler ve sanatsal-sosyal etkinliklere katılım sıklıkları hakkında sorular vardı. Ayrıca Sanata İlişkin Görüşleri Belirleme Ölçeği (SGBÖ), Maslach Tükenmişlik Envanteri-Öğrenci Formu (MTÖ-ÖF) ve Temel Empati Ölçeği (TEÖ) uygulandı.

Bulgular: Araştırmaya 413 öğrenci katıldı. Öğrencilerin \%64,2'si “Sanat”'n “Tıp" ile ilişkili olduğunu düşünürken, Tip Fakültesi öğretim programında böyle bir eğitim almak isteyenlerin oranı sadece $\% 40,2$ idi ( $p<0,001)$. SGBÖ'nden kız öğrencilerin aldıkları puanlar erkek öğrencilere göre anlamlı olarak yüksekti $(\mathrm{p}<0.001)$. Öğrencilerin tükenmişlik riski \%54,5 idi. Ölçeklerden alınan puanların ile sanatsal / sosyal etkinliklere katılım sıklıkları ile karşılaştırıldığında; MTÖÖF'nun duyarsızlaşma alt ölçeği $(p=0.013)$, TEÖ'nin duygusal alt ölçeği $(p=0.015)$ ve TEÖ'nin bilişsel alt ölçekleri ( $p$ $=0.001$ ) ile sanatsal/sosyal faaliyete katılım sıklığı arasında anlamlı farklılık tespit edildi.

Sonuç: Sonuç olarak, bu çalışmanın verileri sanatsal etkinliklere katılmanın öğrencilerin tükenmişlik düzeylerini azalttığını ve empati düzeylerini artırdığını desteklemektedir. Öğrencilere sanatla ilgili dersler verilmesi ya da tıp fakültesi gibi zorlu eğitim koşullarına sahip fakültelerde öğrencilerine sanatsal faaliyetlere ulaşabilecekleri koşulların sağlanması, öğrencilerin tükenmişlik sıklığının azalmasına yardımcı olabilir.

Anahtar sözcükler: Sanat, tükenmişlik, empati, tıp öğrencileri

\section{INTRODUCTION}

It is known how valuable art is for social, personal and practical aspects of medicine and especially for the physician-patient relationship. ${ }^{1}$ Medical educators have begun to recognize the importance of art and humanism as a part of medical education. On the other hand, university education increases the risk of anxiety and depression among students due to adaptation to a new environment, lessons, and worries about the future. It has been shown that the prevalence of depression and anxiety among medical students is widespread. ${ }^{2-6}$ The fact that medical education is long and challenging, the excessive information load and excessive working time in education and the information to be used directly in relation to human health after graduation, that is, the necessity to learn the information completely correctly are the reasons that may cause this height. For this reason, the participation of medical students in social activities, engaging in art and taking these trainings in medical school, it will help them to become better physicians and individuals.

Art is a tool that enables physicians to better understand their work and to cope with the difficulties they face during their profession. Art may also lead to the development of speedy thinking in physicians, and may offer different perspectives or different solutions to the physician in terms of the patient or the decision about the disease. Also art should decrease the anxiety levels and burnout risk and increase empathy. In Turkey, yet very few art classes in medical school is located in the curriculum. ${ }^{7}$ There is a lesson under the name of "Human Sciences in Medicine" in some medical faculties, which includes humanities, social sciences and art and their reflections on medical education and medical practice. ${ }^{8}$

In this study, we aimed to observe the artistic/social activities of medical school students from two different faculties and to evaluate the relationship of doing artistic/social activity and burnout risk and empathy levels of students. And the other aims are to explore the extent to which medical students believe art and science are related, to assess the correlation between undertaking social activities and burnout in medical students.

\section{MATERIAL AND METHODS}

\section{Design}

This is a descriptive study conducted at Cumhuriyet University Medical School (CUMS) and Necmettin Erbakan University Medical School (NEUMS), Turkey.

\section{Participants}

All students, during the 2018-2019 academic year, at two medical faculties in Turkey were included in the study.

\section{Data Collection}

After obtaining the relevant medical faculties permission to carry out the study, the information about the study and the online survey link were sent to all students via e-mail. Participation in the study was voluntary. The first e-mail was sent on 03.15.2019 and online survey link was closed on 06.15.2019. A reminder mail was sent to the students at regular intervals.

\section{Measurement}

The survey that we applied for the study comprised four parts. The first part of the study survey 
included questions to determine demographic data and frequencies of participation in artistic-social activities. The other parts of the survey were Determinant Scale for Opinions about the Art (DSOA), Maslach Burnout Inventory-Student Scale (MBI-SS), and Basic Empathy Scale (BES). ${ }^{9-}$

${ }^{11}$ Turkish forms of the scales were used. We asked permission for using the scales from the authors who made Turkish validity of the scales.

The questions about demographic data and the frequencies

The questions in this part were as follows:

(1) Sex,

(2) Age,

(3) University,

(4) Phase,

(5) Do they attend an artistic course?

(6) If they are attending, is the course organized by the University?

(7) The frequency of artistic activity (never/sometimes/usually),

$(8,9,10,11,12,13,14)$ The frequency of instrument playing, dancing, going to a concert, going to theater/cinema, painting, visiting the museum/browsing an art gallery, reading poetry/books (never/sometimes/usually),

(15) Do they think art and medicine are related? (yes/no/undecided),

(16) Do they think the lecture about "Art and Medicine" should be included in the curriculum of the medical school?

For calculating the score of social activity was assigned 1, 2 and 3 points to each parameter of number 8 - 14 items (never, sometimes, usually), respectively. The scores for each item were summed and the total score was calculated.

Determinant Scale for Opinions about the Art

We used the 25-item "Determinant Scale for Opinions about the Art" ( $\alpha=0.93)$, developed by Ayaydin et al, which aims to find out opinions of undergraduates about the art. DSOA is presented on a five-point Likert scale (1=fully disagree to $5=$ fully agree). There is no cut-off value on the scale. Higher scores indicate positive attitudes about art. ${ }^{9}$

\section{Maslach Burnout Inventory-Student Scale}

Students' burnout was measured by the Maslach Burnout Inventory-Student Scale Turkish adapted version, which scale was developed by Schaufeli and adapted to Turkish by Capri. ${ }^{10,12}$ MBI-SS includes the three subscales (exhaustion, $\alpha=0.76$; cynicism, $\alpha=0.82$; and efficacy, $\alpha=0.61$ ). Responses range across a five-point Likert scale as never (1) to always (5). Capri ${ }^{10}$ thought that the seven-point likert in the original scale did not fit Turkish culture and used a 5-point likert. While the high scores in exhaustion and cynicism subscales indicate burnout, a low score in the efficacy subscale shows burnout. The total score for each subscale (exhaustion, cynicism and efficacy) is categorized "low", "moderate", or "high". "High" means "scoring in the 75th percentile or higher" and "low" means "scoring in the 25th percentile or lower".

\section{Basic Empathy Scale}

Empathy was measured by the Turkish adapted Basic Empathy Scale. Jolliffe and Farrington developed this scale in 2006 and adapted by Topcu et al. to Turkish. ${ }^{11,13}$ BES consists of two subscales (affective empathy, $\alpha=0.76$; and cognitive empathy, $\alpha=0.80$ ) and uses the five-point Likert scale ( $1=$ totally disagree to $5=$ totally agree). Taken higher scores indicates higher levels of empathy. ${ }^{11}$

\section{Data Analysis}

Collected data analyzed with a statistics software package (SPSS for Windows, Version 25.0). Shapiro-Wilk test was used to determine if the data had a normal distribution. Collected data first was used for descriptive statistics. Frequencies for categorical variables and measures of central tendency (Mean \pm Standard Deviation) for continuous variables were calculated. Chi-square test was used to analyze the categorical data. For data with normal distribution, the independent $T$ test was used to compare two independent groups, the one-way ANOVA test was used to compare several independent groups. A p-value of less than 0.05 was considered for statistical significance, with a $95 \%$ confidence interval.

\section{Ethical Approval}

The ethics committee of the Cumhuriyet University Non-Interventional Clinical Research approved this protocol (Approval date/number: 02.20.2019/E2019-02/15). Study permits were obtained from the faculties where the study was conducted. In addition, authors who made the Turkish validity study of the scales used were informed and approved to use.

\section{RESULTS}

A total of 413 students participated in the study and $64.2 \%(n=265)$ of them were from CUMS and $35.8 \%(\mathrm{n}=148)$ were from NEUMS. Response rate 
was $20.6 \%$. The mean age of the participants was $21.3 \pm 2.4$ years, and their ages ranged between 17 and 39. Students' $7.3 \%(\mathrm{n}=30)$ attended an artistic course. Only two of the students who attended an artistic course stated that this course was provided by the university. Table 1 shows students' sociodemographic data and the frequency of participation in artistic activities.

Table 1: Students' sociodemographic data and the frequency of participation in artistic activities

\begin{tabular}{|l|c|c|}
\hline & $\mathrm{n}$ & $\%$ \\
\hline Medical faculty & 265 & 64.2 \\
\hline CUMS & 148 & 35.8 \\
\hline NEUMS & & \\
\hline Phase & 84 & 20.3 \\
\hline I & 80 & 19.4 \\
\hline II & 169 & 40.9 \\
\hline III & 23 & 5.6 \\
\hline IV & 35 & 8.5 \\
\hline V & 22 & 5.3 \\
\hline VI & & 55.4 \\
\hline Sex & 229 & 44.6 \\
\hline Female & 184 & 9.7 \\
\hline Male & & 28.8 \\
\hline Participation in artistic activities & 40 & \\
\hline Never & 254 & \\
\hline Sometimes & 119 & \\
\hline Usually & & \\
\hline CUMS, Cumhuriyet University Medical School; NEUMS, Necmettin Erbakan University \\
Medical School & & \\
\hline
\end{tabular}

The artistic / social activities the students are interested in are given in Table 2.

While 64.2\% ( $\mathrm{n}=265)$ of the students thought that "Art" and "Medicine" were related, the rate of those who wanted such an education in the Faculty of Medicine curriculum was $40.2 \% \quad(n=166)$. This difference was statistically significant $(\mathrm{p}<0.001)$. The scores of the female students in DSOA were significantly higher than the male students $(p<0.001)$. In the comparison of the scale scores according to two universities, a significant difference was found only in cynicism and efficacy subscale of MBI-SS $\quad(p=0.032 ; \quad p=0.006$, respectively). Table 3 shows the comparison of students' demographic data and the scores taken from the scales we applied. 
Table 2: The artistic /social activities the students are interested in

\begin{tabular}{|l|l|l|l|}
\hline $\mathrm{N}=413$ & Never & Sometimes & Usually \\
\hline Playing instrument & $244(59.1 \%)$ & $118(28.6 \%)$ & $51(12.3 \%)$ \\
\hline Dancing & $242(58.6 \%)$ & $132(32.0 \%)$ & $39(9.4 \%)$ \\
\hline Going to a concert & $128(31.0 \%)$ & $227(55.0 \%)$ & $58(14.0 \%)$ \\
\hline Going to theater/cinema & $18(4.4 \%)$ & $159(38.5 \%)$ & $236(57.1 \%)$ \\
\hline Painting & $246(59.6 \%)$ & $124(30.0 \%)$ & $43(10.4 \%)$ \\
\hline Visiting the museum/browsing an art gallery & $123(29.8 \%)$ & $241(58.4 \%)$ & $48(11.9 \%)$ \\
\hline Reading poetry/books & $24(5.8 \%)$ & $131(31.7 \%)$ & $258(62.5 \%)$ \\
\hline
\end{tabular}

Table 4: Maslach Burnout Inventory-Student Survey subscales and risk of burnout

\begin{tabular}{|ccc|}
\hline & $\mathrm{n}$ & $\%$ \\
\hline Exhaustion & 125 & 30.3 \\
Low & 163 & 39.5 \\
Moderate & 125 & 30.3 \\
High & & \\
Cynicism & 135 & 32.7 \\
Low & 174 & 42.1 \\
Moderate & 104 & 25.2 \\
High & 127 & 30.8 \\
Efficacy & 182 & 44.1 \\
Low & 104 & 25.2 \\
Moderate & & 53.2 \\
High & 141 & 56.8 \\
Risk of Burnout ${ }^{\dagger}$ & 84 & 54.5 \\
CUMS & 225 & \\
NEUMS & low efficacy cynicism & \\
Total & & \\
\hline${ }^{\dagger}$ Burnout risk is calculated as follows, high score on emotional exhaustion or cynicism, or & & \\
& & \\
\hline
\end{tabular}


Table 3. The comparison of students' demographic data and the scores are taken from the scales we applied.

\begin{tabular}{|c|c|c|c|c|c|c|c|c|c|c|c|c|}
\hline & \multirow{2}{*}{\multicolumn{2}{|c|}{ DSOA }} & \multicolumn{6}{|c|}{ MBI-SS } & \multicolumn{4}{|c|}{ BES } \\
\hline & & & \multicolumn{2}{|c|}{ Exhaustion } & \multicolumn{2}{|c|}{ Cynicism } & \multicolumn{2}{|c|}{ Efficacy } & \multicolumn{2}{|c|}{ Affective } & \multicolumn{2}{|c|}{ Cognitive } \\
\hline & Mean \pm SD & $\mathrm{p}$ & Mean \pm SD & $\mathrm{p}$ & Mean \pm SD & $\mathrm{p}$ & $\operatorname{Mean} \pm \mathrm{SD}$ & $\mathrm{p}$ & Mean \pm SD & $\mathrm{p}$ & Mean \pm SD & $\mathrm{p}$ \\
\hline \multicolumn{13}{|c|}{ University } \\
\hline CUMS & $96.6 \pm 16.0$ & 0.816 & $16.0 \pm 4.8$ & 0.120 & $10.9 \pm 3.9$ & 0.026 & $11.6 \pm 3.0$ & 0.003 & $38.8 \pm 7.1$ & 0.151 & $35.3 \pm 4.8$ & 0.902 \\
\hline NEUMS & $97.0 \pm 19.2$ & & $16.8 \pm 5.2$ & & $11.8 \pm 4.3$ & & $10.6 \pm 3.0$ & & $39.8 \pm 6.2$ & & $35.3 \pm 4.4$ & \\
\hline \multicolumn{13}{|l|}{ Sex } \\
\hline Female & $100.5 \pm 14.3$ & $<0.001$ & $16.3 \pm 4.8$ & 0.702 & $11.0 \pm 3.7$ & 0.175 & $11.0 \pm 2.7$ & 0.124 & $41.0 \pm 5.7$ & $<0.001$ & $35.7 \pm 4.5$ & 0.080 \\
\hline Male & $92.1 \pm 19.3$ & & $16.1 \pm 5.2$ & & $11.5 \pm 4.6$ & & $11.5 \pm 3.4$ & & $36.8 \pm 7.3$ & & $34.9 \pm 4.8$ & \\
\hline \multicolumn{13}{|l|}{ Phase $^{\dagger}$} \\
\hline Preclinic & $96.1 \pm 17.8$ & 0.091 & $16.0 \pm 4.9$ & 0.104 & $11.0 \pm 4.1$ & 0.070 & $11.2 \pm 3.1$ & 0.299 & $38.9 \pm 6.9$ & 0.065 & $35.4 \pm 4.7$ & 0.488 \\
\hline Clinic & $99.4 \pm 14.5$ & & $17.1 \pm 5.2$ & & $12.0 \pm 4.1$ & & $11.6 \pm 2.9$ & & $40.3 \pm 6.0$ & & $35.0 \pm 4.6$ & \\
\hline
\end{tabular}


Table 4 shows Maslach Burnout Inventory-Student Survey subscales and risk of burnout. There was a statistical difference between students' phases (clinic/preclinic) and risk of burnout $(\mathrm{p}=0.041)$. In clinic the frequency of burnout risk was $\% 63,7$ $(\mathrm{n}=51)$, this rate was $\% 52.3(\mathrm{n}=174)$ in preclinic. A significant relationship was found between participation frequency in artistic activities and cynicism subscale of MBI-SS ( $\mathrm{p}=0.013$ ), affective subscale $(p=0.015)$ and cognitive $(p=0.001)$ subscale of BES. Table 5 shows the comparation of MBI-SS, BES and participation frequency in artistic activities.

Table 5: Maslach Burnout Inventory-Student Scale, Basic Empathy Scale and participation frequency in artistic activities

\begin{tabular}{|c|c|c|c|c|c|c|c|}
\hline \multicolumn{8}{|c|}{ Frequency in artistic activities } \\
\hline & Never & Sometimes & Usually & $\mathrm{p}$ & $\mathrm{p}^{*}$ & $\mathrm{p}^{* *}$ & $\mathrm{p}^{* * * *}$ \\
\hline \multicolumn{8}{|l|}{ MBI-SS } \\
\hline Exhaustion & $18 \pm 5.1$ & $16.2 \pm 4.8$ & $15.7 \pm 5.2$ & 0.053 & 0.043 & 0.016 & 0.375 \\
\hline Cynicism & $13.1 \pm 4.5$ & $11 \pm 4.0$ & $11.1 \pm 4.1$ & 0.013 & 0.004 & 0.009 & 0.898 \\
\hline Efficacy & $10.9 \pm 3.5$ & $11.1 \pm 3.1$ & $11.6 \pm 2.9$ & 0.236 & 0.780 & 0.222 & 0.114 \\
\hline \multicolumn{8}{|l|}{ BES } \\
\hline Cognitive & $36.5 \pm 7.4$ & $39.1 \pm 6.9$ & $40.1 \pm 6.1$ & 0.015 & 0.023 & 0.004 & 0.199 \\
\hline Affective & $33.6 \pm 4.8$ & $35 \pm 4.7$ & $36.5 \pm 4.2$ & 0.001 & 0.062 & 0.001 & 0.004 \\
\hline \multicolumn{8}{|c|}{$\begin{array}{l}\text { MBI-SS, Maslach Burnout Inventory-Student Scale; BES, Basic Empathy Scale } \\
\mathrm{p}^{*} \text {. One way analysis of variance-post-hoc analyses between groups never and sometimes } \\
\mathrm{p}^{* *} \text {. One way analysis of variance-post-hoc analyses between groups never and usually }\end{array}$} \\
\hline
\end{tabular}

\section{DISCUSSION}

In this study, artistic and social activities of medical students and the factors affecting this situation were investigated and the relationship between artistic / social activities and burnout and empathy levels were evaluated. As a result of the study, $28.8 \%$ of the students who participated in the study from two different universities were involved in artistic activities more frequently, $40 \%$ thought that there should be a course about art in the medical faculty, and students who were more interested in artistic activity had more empathy and were less prone to cynicism.

There are some studies in the literature about the social activities of physicians and results vary. ${ }^{14-16}$ In a study published by Ozkara et al., ${ }^{17}$ the interest of family physicians to art evaluated, $57 \%$ of the physicians participating in the study were interested in art; $7.6 \%$ of these physicians have been reported to do art at a professional level. In the literature review, no study was conducted on the status of medical students and their effects on artistic activities in Turkey. When the international publications are examined, it is observed that more than half of the students are engaged in art in the study of the approach of medical students to artistic activities in USA. ${ }^{18}$ In this study, it was determined that $90.3 \%$ of the students were engaged in art in a way and that $28.2 \%$ of them were usually. The fact that the rates in the studies conducted in two different provinces in our country is higher compared to the national and international studies is a positive result especially for the students of medical faculties.

When we evaluated the artistic/social activities of the students are interested in; $62.5 \%$ of them stated that they usually read books/poetry; $57.1 \%$ of students stated that they usually go to theatre / cinema. When we look at the least activities of the students they do; approximately half of them never do painting, playing instrument and dancing. In a study in which assessed of participation of first 
year students of Erciyes (Turkey), students stated that they allocate the $40 \%$ of their money to social activities. ${ }^{14}$ When the authors look at the activities asked to students in this study, all activities except reading books/poetry are activities that require financial support.

In this results, $64.2 \%$ of the students thought that "Art" and "Medicine" were related. Ozkara et al. ${ }^{17}$ stated that $63.6 \%$ of the participants thought that medicine had a relationship with art. The reason for this is that medicine and art, whose main themes are human and life, are intertwined. When the doctor examines his/her patient, he/she can be a kind, wise, sympathetic counsellor, sometimes cheerful, sometimes calm, like an actor. The doctor should understand the nature of the patient by treating his or her illness, not only with the knowledge of the literature but also with an art branch of his / her interest. ${ }^{19}$

In a study conducted in the USA, to assess the frequency of suicidal ideation among medical students and explore its relationship with burnout, burnout was reported by $49.6 \%$ of students. ${ }^{20}$ Santen et al. ${ }^{21}$ reported that burnout progressively develops over the course of medical education. In this study frequency of burnout risk \%63,7 in clinic and $\% 52.3$ in preclinic. Maslach et al. ${ }^{22}$ defined the syndrome of burnout as including high depersonalization and emotional exhaustion with low personal accomplishment. Some studies on medical student burnout exist. One study of Swedish medical students, using a different burnout scale, found no difference in burnout between the first and third years of medical school. ${ }^{23}$ Thomas et al. ${ }^{24}$ have studied students in three Minnesota medical schools and have shown that emotional exhaustion and depersonalization burnout is common and decreased empathy was seen in students with emotional exhaustion and depersonalization burnout. In this study, there was a change in risk of burnout between medical school classes. High levels of burnout in medical school are a result of the increasing degree of difficulty imposed on the students by the classes.

In this study, the most remarkable result was that there was a significant difference between participations' frequency in artistic/social activity and all subscales of BES and cynicism subscale of MBI-SS. Artistic people tend to be creative, expressive, emotional, original, and introspective. According to Holland, ${ }^{25}$ social individuals enjoy working with others, helping them, and providing information. Orkibi ${ }^{26}$ stated that creative arts therapies students and professionals who are more self-expressive, creative, and original (artistic) as well as more communicative, supportive, and interested in helping others (social) are more resilient to the adverse effects of work burnout on career commitment. Mangione et al. ${ }^{27}$ stated that in medical students exposure to the humanities (e.g., music, literature, theatre, visual arts) was significantly correlated with positive personal qualities, including empathy, tolerance for ambiguity, wisdom, emotional appraisal, selfefficacy, and spatial skills, and also it was inversely correlated with some components of burnout.

\section{CONCLUSION}

The main result of this study is that the artistic activity rates in the studies conducted in two different faculties in Turkey are higher compared to the national and international studies is a positive result especially for the students of medical faculties and engaging in artistic activities increases empathy levels. This result shows that it is necessary to add artistic courses to the faculty students who have severe educational conditions such as medical school or to direct them to artistic activities and to provide the conditions that can reach these activities.

\section{Limitation}

The low student participation rate is a limitation of the study. Reminder messages were sent to the students at regular intervals for the online study link, but there was limited participation due to the participation in the study was on a voluntary basis. Another limitation is research done on social media might be considered less reliable. Survey link was sent from the online group which is using by only medical faculty students. This situation can be seen as an advantage over face-to-face survey method rather than a limitation. Participants could express their real thoughts on this matter without any hesitation.

\section{Disclosure statement}

The authors report no conflicts of interest. The authors alone are responsible for the content and writing of this article.

\section{Funding}

The authors report no funding.

\section{REFERENCES}

1. Triana JE. Humanistic and social education for physicians: the experience of the Colombian School of Medicine. J Med Philos 1996; 21(6):651-657.

2. Bíró E, Balajti I, Adány $\mathrm{R}$, Kósa $\mathrm{K}$. Determinants of mental well-being in 
medical students. Soc Psychiatry Psychiatr Epidemiol 2010; 45(2):253-258.

3. Sarikaya O, Civaner M, Kalaca S. The anxieties of medical students related to clinical training. Int J Clin Pract 2006; 60(11):1414-1418.

4. Peng L, Zhang J, Li M, et al. Negative life events and mental health of Chinese medical students: the effect of resilience, personality and social support. Psychiatry Res 2012; 196(1):138-141.

5. Baykan Z, Nacar M, Cetinkaya F. Depression, anxiety, and stress among lastyear students at Erciyes University Medical School. Acad Psychiatry 2012; 36(1):64-65.

6. Oncu B, Sahin T, Ozdemir S, et al. Depression, anxiety and stress status among medical students and associated factors. Kriz Dergisi 2013; 21:1-10.

7. Akman M, Unalan P, Kalaca S. Tip eğitiminde sanatın yeri. Hacettepe Medical Journal 2009; 40(1):1-5.

8. Elcin M, Odabas1 O, Ward $\mathrm{K}$, et al. The first medical humanities programme in Turkey. Med Educ 2006; 40:278-282.

9. Ayaydın A, Kurtuldu MK, Akyol Dayı B. Developing a determinant scale for opinions about the art. İnönü University Journal of the Faculty of Education 2017; 18(1):204-219.

10. Capri B, Gunduz B, Gokcakan Z. Maslach tükenmişlik envanteri-öğrenci formu'nun (MTE-OF) Türkçe'ye uyarlaması: geçerlik ve güvenirlik çalışması. Çukurova Üniversitesi Eğitim Fakültesi Dergisi 2011; 1(40):134-147.

11. Topcu C, Baker OE, Aydin YC. Turkish adaptation of basic empathy scale: validity and reliability study. Türk Psikolojik Danışma ve Rehberlik Dergisi 2010; 4(34):174-182.

12. Schaufeli WB, Martinez I, Marques-Pinto A, Salanova M, Bakker A. Burnout and engagement in university students: A cross-national study. Journal of Crosscultural Studies 2002; 33:464-481.

13. Jolliffe D, Farrington DP. Development and validation of the Basic Empathy Scale. Journal of Adolescence 2006; 29:589-611.

14. Bulut A, Baykan Z, Nacar M. Assessment of participation of first year students of
Erciyes University Medical Faculty to social activities. Tip Eğitimi Dünyas1 2018; 52(17):56-69.

15. Akdogan I, Ozdel O, Akdogan D, Topal K. Evaluation of humanities in medicine program by grade 1 and grade 2 students of Pamukkale University Medical School. Pamukkale Medical Journal 2016; 9(1):3944.

16. Akar M. The effect of visual arts in medical education. Sosyoloji Dergisi 2015; 3(30):355-380.

17. Ozkara A, Sumer S, Baser DA, et al. The artistic activities of family physicians. Konuralp Medical Journal 2015; 7(1):3439.

18. Rodenhauser P, Strickland MA, Gambala CT. Arts-related activities across U.S. medical schools: a follow-up study. Teach Learn Med 2004; 16(3):233-239.

19. O'Donnell M. Doctors as performance artists. J R Soc Med 2005; 98(7):323-324.

20. Dyrbye LN, Thomas MR, Massie FS, et al. Burnout and suicidal ideation among U.S. medical students. Ann Intern Med 2008; 149(5):334-341.

21. Santen SA, Holt DB, Kemp JD, Hemphill RR. Burnout in medical students: examining the prevalence and associated factors. South Med J 2010; 103(8):758763.

22. Maslach C, Jackson SE, Leiter MP. Maslach burnout inventory. In: Zalaquett CP, Wood RJ, editors. Evaluating stress: A book of resources. Lanham: Scarecrow Education, 1997; 191-218.

23. Dahlin ME, Runeson B. Burnout and psychiatric morbidity among medical students entering clinical training: a threeyear prospective questionnaire and interview-based study. BMC Med Educ 2007; 7:6.

24. Thomas MR, Dyrbye LN, Huntington JL, et al. How do distress and well-being relate to medical student empathy? A multicenter study. J Gen Intern Med 2007; 22(2):177183.

25. Holand JL. Making vocational choices: A theory of vocational personalities and work environments. 3rd ed. Odessa: Psychological Assessment Resources, 1997. 
26. Orkibi H. Highly artistic-social personalities buffer the effects of burnout on career commitment. The Arts in Psychotherapy 2016; 50:75-83.
27. Mangione S, Chakraborti C, Staltari G, et al. Medical students' exposure to the humanities correlates with positive personal qualities and reduced burnout: A multi-institutional U.S. survey. J Gen Intern Med 2018; 33(5):628-634. 